\title{
EKSPLORASI PEMAHAMAN RELASIONAL SISWA SMP BERKEMAMPUAN MATEMATIKA TINGGI DALAM PEMECAHAN MASALAH LINGKARAN
}

\author{
Murtalib $^{1}$, Dewi Silviana ${ }^{2}$, Gunawan $^{3}$ \\ 1, $2 \& 3$ Dosen Program Studi Pendidikan Matematika, STKIP BIMA \\ 1e-mail: murtalib1987@gmail.com
}

\begin{abstract}
ABSTRAK
Penelitian ini bertujuan mendeskripsikan pemahaman relasional siswa SMP yang berkemampuan matematika tinggi dalam pemecahan masalah lingkaran. Jenis penelitian ini adalah penelitian deskriptif dengan menggunakan pendekatan kualitatif. Penelitian ini dilaksanakan di SMP N 3 Belo dengan subjek penelitian adalah kelas VIII. Subjek penelitian terdiri dari satu orang siswa dengan kemampuan matematika tinggi. Tahap penelitian dimulai dari pemilihan subjek penelitian yang ditentukan berdasarkan tes kemampuan matematika, kemudian wawancara berbasis tugas melalui tes pemecahan masalah lingkaran. Untuk menguji keabsahan data dilakukan dengan menggunakan triangulasi waktu. Data pada penelitian ini difokuskan pada hasil wawancara berbasis tugas. Prosedur analisis data meliputi : kategorisasi data, reduksi data, penyajian data, interpretasi data, dan penarikan kesimpulan. Hasil penelitian menunjukkan bahwa pemahaman relasional siswa SMP berkemampuan matematika tinggi dalam pemecahan masalah lingkaran pada setiap tahap pemecahan masalah memenuhi semua indikator komponen pemahaman relasional.
\end{abstract}

Kata Kunci: Pemahaman Relasional, Pemecahan Masalah Lingkaran, Kemampuan Matematika 


\begin{abstract}
This research's aims to describe the relasional understanding of junior high school students within a high matematics ability in circle problem solving. This research is a research descriptive by using qualitative approach. This research executed in SMPN 3 Belo with subjects is grade $8^{\text {th }}$. The subjects are consisted of three students with a low, a moderate, and a high mathematics ability. The steps of this research is started from selection which are determined based on test of mathematical ability, then interview based task. To test data validity is conducted by using time triangulation. Data at this research focused at interview based task result. Data analysis procedure include : categorization, reduction, presentation, interpretation, and conclusion. The research result showed that the relasional understanding of junior high school student within a high matematics ability in circle problem solving at each stage of problem solving met all indicators of relational understanding.
\end{abstract}

Keyword: Relational Understanding, Circle Problem Solving, Mathematics Ability. 


\section{PENDAHULUAN}

Perkembangan ilmu dan teknologi yang sangat pesat pada beberapa dekade belakangan ini merupakan sesuatu yang tidak bisa dilepaskan dari peran matematika sehingga menempatkan ilmu matematika sebagai Ratu sekaligus sebagai Pelayan bagi ilmu pengetahuan lain (Arifin, 2009). Penempatan ini tidaklah berlebihan, karena pada kenyataanya matematika memiliki daya aplikatif yang cukup tinggi bagi pengembangan ilmu pengetahuan lain. Sebagai contoh, konsep kalkulus (khususnya persamaan differensial) menjadi sumber inspirasi bagi ditemukannya cabang-cabang ilmu fisika modern maupun kimia modern. Hukum penawaran dan permintaan dalam ilmu ekonomi dikembangkan atas dasar konsep fungsi, dan kalkulus (khususnya diferensial dan integral). Para ahli astronomi dapat menentukan jarak antara bintang dan benda-benda angkasa lainya berkat konsep trigonometri. Bahkan perkembangan terakhir, peran matematika sangat kuat pada bidang-bidang ilmu lain yang tak terduga sebelumnya, seperti teori "ketepatan sasaran" dalam ilmu olahraga dikembangakan dari konsep trigonometri, teori "aransemen musik" dikembangkan dari konsep fungsi (khususnya barisan) dan masih banyak lagi peranan matematika untuk kemajuan ilmu pengetahuan dan teknologi.

Memperhatikan begitu besarnya peranan matematika di atas, maka memahami konsep matematika sangat diperlukan bagi penguasaan matematika sejak dini sampai pada jenjang yang lebih tinggi. Salah satu jenis pemahaman konsep matematika adalah pemahaman relasional. Skemp (1976) mendefinisikan "Relational understanding is described as knowing both what to do and why". Pemahaman relasional adalah kemampuan seseorang menggunakan prosedur matematis dengan penuh kesadaran bagaimana dan mengapa ia menggunakan prosedur tersebut. Selanjutnya pada tahun 1987 Skemp merevisi pengertian pemahaman relasional menjadi "Relational understanding is the ability to deduce specific rules or procedure from more general mathematical relationships". Artinya pemahaman relasional adalah kemampuan untuk menurunkan suatu aturan atau prosedur khusus dari hubungan matematik yang lebih umum.

Senada dengan pernyataan Skemp di atas, Shadiq (2008) menjabarkan pemahaman relasional sebagai kemampuan seseorang menggunakan suatu prosedur matematis yang berasal dari hasil menghubungkan berbagai konsep matematis yang relevan dalam menyelesaikan suatu masalah dan mengetahui mengapa prosedur tersebut dapat dipergunakan. Lebih lanjut Shadiq (2008) menyatakan bahwa siswa yang memiliki pemahaman relasional dapat mengaitkan sesuatu dengan hal lainnya secara benar dan 
menyadari proses yang dilakukan. Dari uraian di atas, dapat diketahui bahwa siswa yang memiliki pemahaman relasional mampu mengenali kaitan antar konsep dan prosedur, dan dapat memberikan alasan yang tepat untuk menjelaskan konsep dan prosedur matematik yang digunakan dalam menyelesaikan tugas matematik atau soal matematik. Sebagai contoh, ketika siswa SMP diberikan pertanyaan berapa hasil dari $3 \times 6$, maka siswa yang memiliki pemahaman relasional tidak hanya mampu menjawab pertanyaan itu dengan benar yaitu adalah 18 tetapi juga dapat menjelaskan mengapa $3 \times 6=18$ ? yaitu 18 diperoleh dari hasil penjumlahan berulang bilangan 6 sebanyak tiga kali $(6+6+6=18)$. Contoh lain terkait dengan gambaran pemahaman relasional siswa yang dapat ditemukan peneliti saat observasi awal di SMPN 3 Belo Bima adalah ketika 20 orang siswa kelas VIII diberikan pertanyaan terkait materi lingkaran,"berapakah besar sudut setengah lingkaran?”. Hasilnya menunjukkan sebanyak 15 orang menjawab dengan benar $180^{\circ}, 5$ orang tidak bisa menjawab dengan benar. Ketika 15 orang tersebut diberi pertanyaan lanjutan "coba jelaskan bagaimana kamu tahu besar sudut setengah lingkaran tersebut $180^{0}$ ?". Hasilnya menunjukkan dari 15 orang siswa yang menjawab benar tersebut hanya 2 orang yang mampu menjelaskan dengan tepat, yaitu sudut setengah lingkaran dibentuk dari dua buah garis yang tegak lurus yaitu sebuah diameter lingkaran dengan sebuah jarijari lingkaran sehingga membentuk sudut berpelurus.

Salah cara untuk mengetahui gambaran pemahaman relasional siswa secara utuh adalah dapat dilihat dari aktivitas siswa menyelesaikan soal matematika yang menantang yang tidak segera dapat diselesaikan dengan prosedur rutin. Aktivitas ini selanjutnya disebut pemecahan masalah. Polya (2004) mendefinisikan pemecahan masalah (problem solving) sebagai "to search consciously for some action appropriate to attain a clearly conceived, but not immediately attainable, aim”. Makna dari pernyataan tersebut adalah pemecahan masalah sebagai usaha sadar untuk mencari jalan keluar dari suatu kesulitan, tetapi tujuan tersebut tidak segera dapat dicapai. Hudojo (2005) mendefinisikan pemecahan masalah adalah proses yang ditempuh seseorang untuk menyelesaikan masalah yang dihadapinya sampai masalah itu tidak lagi menjadi masalah baginya. Wardhani (2008) menyatakan pemecahan masalah adalah proses menerapkan pengetahuan yang telah diperoleh sebelumnya ke dalam situasi baru yang belum dikenal. Kemudian menurut Siswono (2008), pemecahan masalah adalah suatu proses atau upaya individu untuk 
merespon atau mengatasi halangan atau kendala ketika jawaban atau metode suatu jawaban belum tampak jelas.

Berkenaan dengan apa yang didapatkan siswa dari melakukan suatu pemecahan masalah. Cooney, Davis, \& Henderson (dalam Wahyudin, 2003) juga berpendapat bahwa dengan mengajarkan siswa untuk menyelesaikan masalah, memungkinkan siswa menjadi lebih analitik dalam mengambil keputusan di dalam kehidupannya. Masalah yang diangkat dalam penelitian ini adalah masalah lingkaran berupa soal penerapan konsep lingkaran dalam kehidupan sehari-hari. Beberapa hasil penelitian melaporkan bahwa masih banyak siswa yang mengalami kesulitan dalam menyelesaikan masalah lingkaran terkait dengan soal cerita. Hal ini sesuai dengan laporan Prasetyo (2010) berikut.

"Penyebab rendahnya pemahaman siswa dalam mempelajari lingkaran adalah kurang memiliki strategi pemecahan masalah berupa penulisan langsung jawaban tanpa disertai penulisan mengenai apa yang diketahui dan apa yang ditanyakan pada soal cerita dan kurangnya pemahaman siswa mengenai kalimatkalimat matematika yang ada pada soal cerita. Kesalahan lain juga terjadi pada saat menentukan metode dan formula yang digunakan".

Alasan peneliti memilih masalah lingkaran untuk dikaji dalam penelitian ini selain masih banyak kesulitan yang dilakukan siswa dalam memecahkan masalah sebagaimana hasil laporan dari Prasetyo di atas, materi lingkaran juga memiliki terapan yang sangat tinggi dalam kehidupan sehari-hari. Hal ini sesuai dengan pernyataan National Council Teacher Mathematics (NCTM, 2000) "Geometry is a natural place for development of students reasoning and justification skills". Lingkaran sebagai salah satu materi pada bidang geometri tidak hanya diterapkan di sekolah saja tetapi materi ini erat kaitannya dengan kehidupan sehari-hari, juga materi ini merupakan salah satu cabang materi geometri dasar yang dapat dipandang sebagai latihan untuk menata nalar atau wawasan keruangan siswa. Alasan lain peneliti perlu mengkaji masalah lingkaran dalam penelitian ini, karena materi lingkaran merupakan materi prasyarat untuk materi geometri lain seperti bangun ruang sisi lengkung, dan juga merupakan syarat untuk menempuh materi matematika ke jenjang SMA dan perguruan tinggi.

Sementara alasan peneliti memilih siswa SMP karena pada jenjang ini siswa sudah berusia 11 tahun ke atas. Menurut Piaget (2001), pada usia tersebut siswa memasuki tahap operasi formal (formal operation) dimana siswa mulai mampu untuk berpikir abstrak. Salah satu ciri pada tahap ini adalah siswa mampu untuk mempertimbangkan suatu pemecahan masalah dalam kehidupan sehari-hari. Dalam penelitian ini subjek yang akan diambil adalah siswa SMP kelas VIII. Alasan dipilihnya kelas VIII dalam penelitian ini dengan pertimbangan bahwa siswa kelas VIII sudah mempelajari konsep tentang luas dan 
keliling bangun datar serta konsep tentang sudut dan garis yang merupakan prasyarat untuk memahami materi lingkaran.

Hiebert \& Carpenter (dalam et. Bamby, 2007) menyatakan bahwa kualitas pemahaman seseorang sangat ditentukan oleh kaya tidaknya hubungan jaringan ide yang dimiliki oleh seseorang. Lebih lanjut Hiebert \& Carpenter menyatakan bahwa kualitas pemahaman matematik seseorang dapat dilihat dari kemampuannya merelasikan konsepkonsep matematik yang dipahami dengan konsep yang baru pada skema yang tepat khususnya ketika menghadapi suatu pemecahan soal. Hal ini memungkinkan siswa yang memiliki kemampuan matematika tinggi juga memiliki kualitas pemahaman relasional yang lebih baik. Menurut Widhiharto (2008) ada beberapa faktor yang mempengaruhi tingkat perbedaan kemampuan seseorang dalam memahami konsep matematika diantaranya : memiliki pengetahuan prasyarat yang memadai, menguasai konsep, prinsip dan algoritma dengan baik. Siswa yang berkemampuan matematika tinggi cenderung memiliki jaringan konsep yang kaya dan mampu menguasai konsep, prinsip, algoritma yang memadai sehingga dapat menyelesaikan soal/tugas matematika dengan hasil yang lebih baik dan juga mampu menjelaskan penggunaan prosedur matematik atau hasil jawaban yang diperoleh dengan benar.

Berdasarkan uraian di atas, maka tujuan penelitian ini adalah mendeskripsikan pemahaman relasional siswa SMP yang berkemampuan matematika tinggi dalam pemecahan masalah lingkaran. Untuk mencapai tujuan penelitian tersebut maka indikator pemahaman relasional dalam penelitian ini dapat ditunjukkan pada Tabel 1 berikut .

Tabel 1

Indikator Pemahaman Relasional dalam Pemecahan Masalah Lingkaran

\begin{tabular}{|l|l|l|}
\hline \multicolumn{2}{|c|}{ Komahaman Relasional } & \multicolumn{2}{c|}{ Indikator } \\
\hline $\begin{array}{l}\text { Mampu mengaitkan konsep baru dengan } \\
\text { konsep yang telah dipelajari untuk } \\
\text { membangun prosedur matematik dalam } \\
\text { penyelesaian masalah }\end{array}$ & $\begin{array}{l}\text { a. Mampu mengenali kaitan konsep-konsep yang relevan } \\
\text { (konsep lingkaran dengan konsep segitiga sama sisi dan } \\
\text { persegi panjang). } \\
\text { b. Mampu menggunakan sifat, simbol, rumus atau algoritma } \\
\text { dengan tepat. } \\
\text { c. Mampu mengaitkan konsep yang relevan dengan operasi } \\
\text { hitung yang tepat untuk mendapatkan kesimpulan yang benar }\end{array}$ \\
\hline $\begin{array}{l}\text { Mampu menjelaskan penggunaan } \\
\text { prosedur matematik dalam menemukan } \\
\text { jawaban masalah. }\end{array}$ & $\begin{array}{l}\text { a. Mampu menjelaskan prosedur atau langkah-langkah } \\
\text { penyelesaian masalah dengan benar . } \\
\text { b. Mampu menjelaskan secara logis alasan penggunaan } \\
\text { rumus/algoritma dalam menyelesaikan masalah } \\
\text { c. Mampu menjelaskan sifat dari konsep-konsep yang dikenali } \\
\text { untuk mendukung prosedur yang digunakan. }\end{array}$ \\
\hline
\end{tabular}




\section{METODE PENELITIAN}

Jenis penelitian ini adalah penelitian deskriptif dengan pendekatan kualitatif yang ide data utamanya berupa kata-kata yang terangkai dalam kalimat. Peneliti mempelajari dan mengungkap pemahaman relasional siswa melalui data hasil tes pemecahan masalah maupun hasil wawancara. Subjek penelitian ini adalah satu orang berkemampuan matematika tinggi dengan skor $80 \leq$ skor $\leq 100$, yang memiliki kriteria : (1) siswa bersedia untuk dijadikan subjek, (2) bisa berkomunikasi baik lisan maupun tulisan, dan 3) berjenis kelamin sama. Instrumen dalam penelitian ini ada dua yaitu instrumen utama dan instrumen pendukung. Instrumen utama yaitu peneliti sendiri, dan instrumen pendukung, yaitu: Tes Kemampuan Matematika (TKM) untuk menjaring subjek penelitian, Tes Pemecahan Masalah Lingkaran (TPML), dan pedoman wawancara. Data dalam penelitian ini adalah respon siswa terhadap TPML-1, TPML-2, dan hasil wawancara. Untuk memvalidasi data digunakan triangulasi waktu. Teknik analisis data meliputi kegiatan : kategorisasi data, reduksi data, penyajian data, interpretasi data, dan penarikan kesimpulan (Miles \&Huberman, 2009).

\section{HASIL DAN PEMBAHASAN}

\section{Pembahasan}

Adapun Tes Pemecahan Masalah Lingkaran (TPML) yang digunakan dalam penelitian ini seperti ditunjukkan pada gambar 1 berikut.

Soal 1 (TPML-1):

Perhatikan gambar berikut !

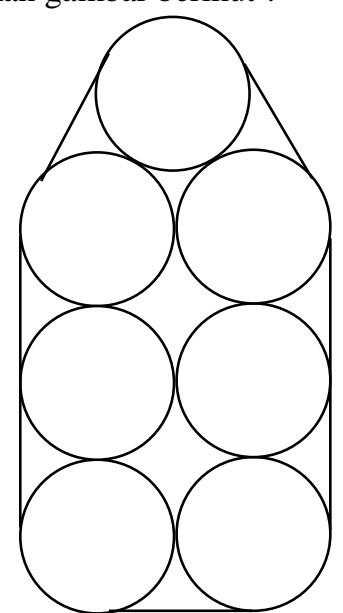

Gambar di atas adalah penampang 7 paralon yang akan diikat dengan menggunakan tali. Berapa panjang tali terpendek agar dapat mengikat penampang paralon-paralon itu jika diameter paralon $10 \mathrm{~cm}$ ? (pilih $\pi=3,14)$ !
Soal 2 (TPML-2):

Perhatikan gambar berikut!

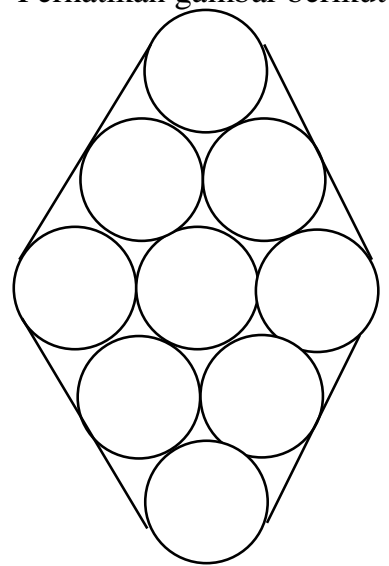

Gambar di atas adalah penampang 9 paralon yang akan diikat dengan menggunakan tali. Berapa panjang tali terpendek agar dapat mengikat penampang paralon-paralon itu jika diameter paralon $10 \mathrm{~cm}$ ? (pilih $\pi=3,14)$ ! 
Deskripsi pemahaman relasional siswa yang berkemampuan matematika tinggi dari masing-masing indikator pemahaman relasional dari setiap tahapan pemecahan masalah adalah :

Pada tahap memahami masalah, siswa yang berkemampuan matematika tinggi mengaitkan hal yang ditanyakan dan hal yang diketahui dengan jalan mengkonstruksi gambar. Siswa yang berkemampuan matematika tinggi mengkonstruksi gambar dengan benar (gambar sesuai permasalahan). siswa yang berkemampuan matematika tinggi mengkonstruksi gambar hanya satu kali. Hal ini menunjukkan bahwa siswa yang berkemampuan matematika tinggi memahami masalah yang diberikan, karena mampu mengaitkan informasi baru dengan skema yang dimilikinya. Hal ini senada dengan pendapat Anderson \& karthwol (2001) "Students are said to understand when they are able to construct meaning from instructional messages". Pernyataan ini dapat diartikan bahwa siswa tergolong paham jika makna dari suatu pengajaran dapat dibangun oleh mereka. Dengan kata lain, seorang tergolong paham jika pengetahuan baru yang sedang dipelajari dapat dikaitkan dengan skema atau kerangka kerja kognitif pada pikirannya.

Pada tahap menyusun rencana, dalam hal kemampuan mengaitkan konsep baru dengan konsep yang dipahami untuk membangun prosedur, berdasarkan gambar yang dikonstruksinya, subjek berkemampuan matematika tinggi mengenali konsep : 1) lingkaran, 2) jari-jari lingkaran, 3) segitiga sama sisi/besar sudut segitiga sama sisi $\left.\left(60^{\circ}\right), 4\right)$ garis singgung persekutuan luar, 5) besar sudut pusat di depan busur, 6) besar sudut satu putaran $\left.\left(360^{\circ}\right), 7\right)$ persegi panjang/besar sudut persegi panjang $\left.\left(90^{\circ}\right), 8\right)$ keliling lingkaran, 9) busur lingkaran. Untuk menyelesaikan masalah, subjek berkemampuan matematika tinggi merencanakan menggunakan rumus keliling lingkaran, rumus panjang busur, rumus garis singgung persekutuan luar lingkaran, dan dalil jumlah sudut satu putaran penuh $=$ $360^{\circ}$ (digunakan untuk mencari/menghitung besar sudut pusat didepan busur). Kemudian dalam hal kemampuan menjelaskan penggunaan prosedur matematik, siswa berkemampuan matematika tinggi mampu menjelaskan sifat-sifat dari konsep yang dikenali dengan tepat. yaitu : sifat segitiga sama sisi, sifat persegi panjang, sifat garis tegak lurus, dan sifat garis singgung lingkaran. Selanjutnya siswa yang berkemampuan matematika tinggi mampu menjelaskan prosedur atau langkah-langkah penyelesaian masalah dengan benar. kemudian dalam hal kemampuan menjelaskan penggunaan rumus, 
siswa berkemampuan matematika tinggi mampu menjelaskan secara logis alasan menggunakan rumus keliling lingkaran dalam penentuan panjang busur.

Pada tahap melaksanakan rencana, dalam hal kemampuan mengaitkan konsep baru dengan konsep yang dipahami untuk membangun prosedur, siswa yang berkemampuan matematika tinggi menggunakan rumus keliling lingkaran, rumus panjang busur, dalil jumlah sudut satu putaran penuh $/ 360^{\circ}$ dengan tepat untuk menyelesaikan masalah. Siswa yang berkemampuan matematika tinggi tidak menggunakan rumus garis singgung peresekutuan luar lingkaran untuk menentukan panjang garis singgung karena menganggap panjang garis singgung sama panjangnya dengan panjang sisi persegi panjang atau panjang sisi segitiga sama sisi. Siswa yang berkemampuan matematika tinggi juga menegaskan bahwa alasannya tidak menggunakan rumus garis singgung persekutuan luar karena jari-jari lingkaran yang bersinggungan sama panjang sehingga panjang garis singgung persekutuan luar lingkaran sama penjangnya dengan segitiga sama sisi atau panjang sisi persegi panjang. Kemudian untuk menemukan jawaban masalah siswa yang berkemampuan matematika tinggi mengaitkan panjang busur dan panjang garis singgung yang diperoleh melalui operasi hitung yang tepat sesuai rencana yaitu menjumlahkan semua panjang busur dengan garis singgung persekutuan luar lingkaran. Hasilnya menunjukkan jawaban/kesimpulan akhir yang diperoleh siswa yang berkemampuan matematika tinggi menemukan jawaban masalah dengan benar. Kemudian dalam hal kemampuan menjelaskan penggunaan prosedur matematik, siswa yang berkemampuan matematika tinggi mampu menjelaskan secara logis alasan menentukan besar sudut pusat dalam penentuan panjang busur. Siswa yang berkemampuan matematika tinggi mampu menjelaskan secara logis menentukan panjang garis singgung luar dan mampu menjelaskan secara logis hasil hitungan dari jawaban yang diperoleh.

Pada tahap memeriksa kembali, dalam hal kemampuan mengaitkan konsep baru dengan konsep yang dipahami untuk membangun prosedur siswa yang berkemampuan matematika tinggi mampu mengaitkan penyelesaiannya dengan apa yang diminta soal dengan melakukan pemeriksaan sebanyak dua kali yaitu di lembar coret-coretan dan lembar jawaban, serta merasa yakin dengan jawabannya dan tidak mempunyai alternatif jawaban lain. Kemudian dalam hal kemampuan menjelaskan penggunaan prosedur matematik, siswa yang berkemampuan matematika tinggi menjelaskan secara logis hasil operasi hitung, penggunaan rumus dalam memeriksa penyelesaian yang telah dilakukan. 
Berdasarkan uraian di atas, menunjukkan bahwa siswa yang berkemampuan matematika tinggi mampu menemukan solusi masalah dengan benar sebagai hasil mengaitkan konsep baru dengan konsep yang dipahami sebelumnya melalui operasi hitung yang tepat. Hal ini menunjukkan bahwa subjek siswa yang berkemampuan matematika tinggi mampu menggunakan prosedur matematik sebagai hasil mengaitkan konsep baru dengan konsep-konsep yang dipahami sebelumnya. Kenyataan ini sesuai dengan pernyataan Skemp (1987) yang menyatakan bahwa siswa yang memiliki pemahaman relasional akan mampu menghubungkan suatu konsep terhadap suatu masalah yang dihadapinya dan mengadaptasi konsep tersebut ke permasalahan baru. Kaitan antar konsep baru dengan konsep yang dipahami siswa yang berkemampuan matematika tinggi dan kaitan antara konsep dengan operasi hitungnya dapat digambar dengan diagram berikut.

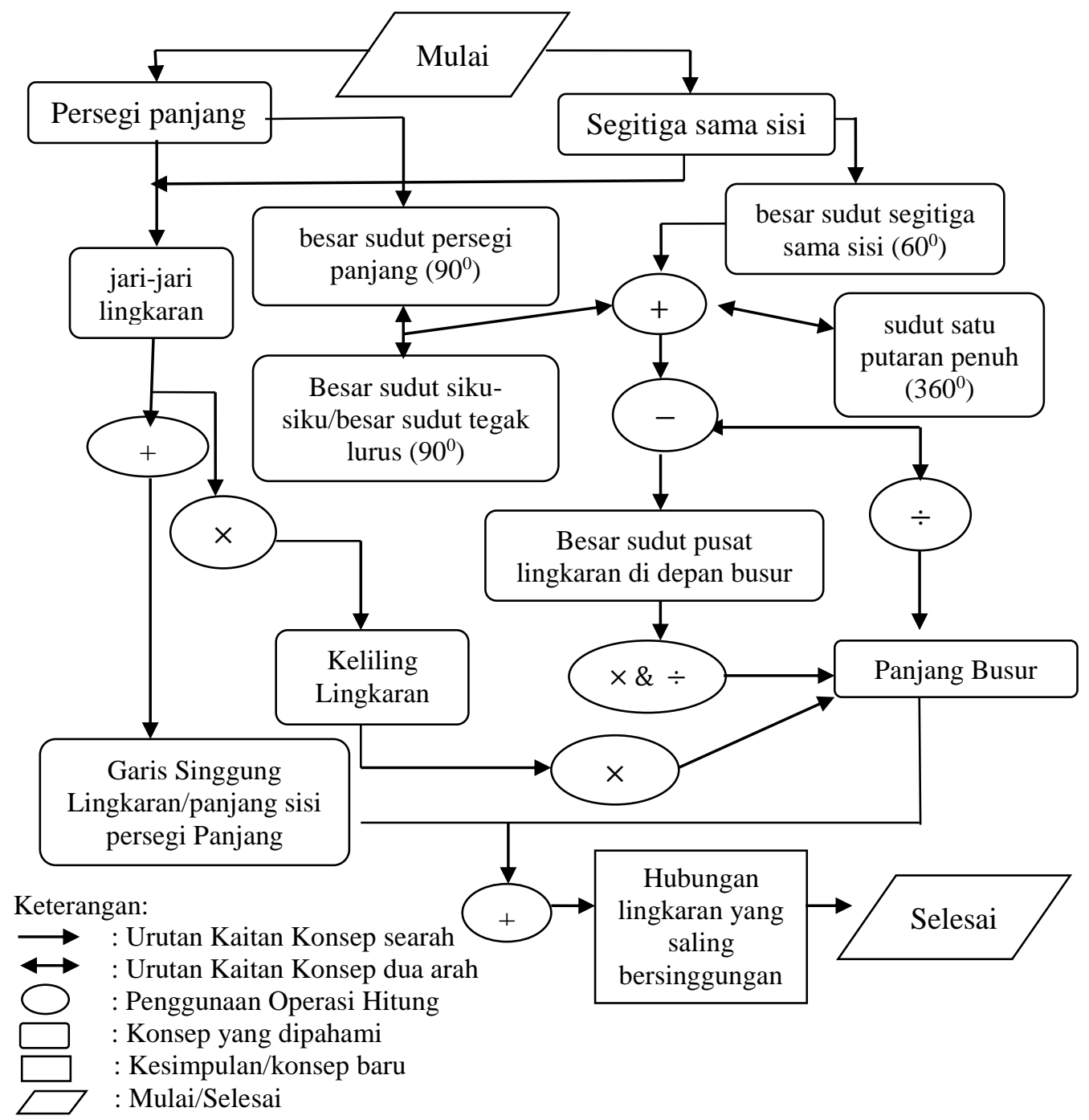

Gambar 2.

Diagram Alur Kaitan Konsep-Konsep yang Dipahami Siswa yang Berkemampuan Matematika Tinggi dalam Pemecahan Masalah Lingkaran 
Jika diperhatikan lebih lanjut uraian di atas, menunjukkan siswa yang berkemampuan matematika tinggi mampu mengkonstruksi hubungan antar konsep, baik antar materi matematika, di dalam materi matematika, maupun di luar matematika. Hubungan antara materi matematika yang dimaksud, seperti hubungan antara persegi panjang, segitiga sama sisi, jari-jari lingkaran untuk menentukan panjang garis singgung persekutuan luar dan besar sudut pusat yang dikaitkan melalui operasi hitung penjumlahan (+) dan pengurangan (-). Sedangkan hubungan di dalam materi matematika, seperti : hubungan antara panjang busur dengan keliling lingkaran, besar sudut pusat dan besar sudut satu putaran penuh $\left(360^{\circ}\right)$ yang dikaitkan dengan operasi hitung pembagian $(\div)$ dan perkalian (X). Selanjuntya hubungan matematika di luar matematika seperti hubungan antara materi matematika dengan kehidupan sehari-hari, pada penelitian ini hubungan yang dimaksud adalah menghubungkan penampang paralon yang diikat dengan cara mengkonstruksi gambar tersebut sehingga membentuk persegi panjang dan segitiga sama sisi dan dengan mudah menemukan cara menentukan panjang tali terpendek untuk mengikat penampang paralon tersebut. Kemampuan mengkonstruksi hubungan konsep matematika tersebut menurut Hamdani (2013) disebut kemampuan koneksi matematika. Hal ini menunjukkan bahwa pemahaman relasional erat kaitannya dengan koneksi matematika. Penyataan ini selaras dengan hasil penelitian Hamdani (2013) yang menyatakan bahwa siswa yang memiliki pemahaman relasional dapat mengkonstruksi hubungan matematika, baik antar materi matematika, maupun di dalam materi matematika

Berdasarkan uraian di atas, juga menunjukkan bahwa kualitas pemahaman relasional siswa yang berkemampuan matematika tinggi sangat optimal. siswa yang berkemampuan matematika tinggi memiliki jaringan konsep yang luas, memiliki pengetahuan prasyarat yang memadai, menguasai konsep, prinsip, rumus/algoritma dengan baik, mampu menemukan solusi masalah dengan benar serta mampu menjelaskan semua sifat dari konsep yang dikenal dengan tepat (seperti sifat konsep garis tegak lurus, dan sifat garis singgung), juga mampu menjelaskan prosedur matematik (menjelaskan alasan penggunaan rumus) dengan benar atau atau mampu menjelaskan hasil jawaban yang diperoleh dengan benar.

Uraian di atas senada dengan pendapat Shadiq (2008) menyatakan bahwa kualitas pemahaman matematik terutama kualitas pemahaman relasional siswa berbeda-beda pada setiap tingkat kemampuan matematika. Pernyataan ini juga didukung oleh pernyataan Widhiharto (2008) ada beberapa faktor yang mempengaruhi tingkat perbedaan kemampuan 
seseorang dalam memahami konsep matematika diantaranya : 1) memiliki pengetahuan prasyarat yang memadai, 2) menguasai konsep, prinsip dan algoritma dengan baik.

\section{Temuan-Temuan Lain}

Temuan lain dalam penelitian ini adalah temuan yang tidak direncanakan sejak awal tetapi perlu untuk diungkapkan karena temuan tersebut turut memberikan kontribusi tentang pemahaman relasional siswa ketika memecahkan masalah lingkaran seperti yang telah digambarkan sebelumnya. Untuk dapat mengungkapkan temuan yang terjadi dalam penelitian ketika subjek mengerjakan tugas pemecahan masalah dan melalui proses wawancara, di sini peneliti meninjau secara umum semua aspek yang mempengaruhi segala aktivitas siswa selama penelitian berlangsung. Adapun temuan-temuan tersebut antara lain adalah sebagai berikut.

Pada saat diwawancarai siswa yang berkemampuan matematika tinggi mudah mengemukakan idenya secara tegas dan cepat tanpa hambatan yang berarti sehingga tidak memerlukan waktu yang lama dan mampu meyakini orang lain atas jawaban yang diperoleh. Jika diperhatikan dari jawaban tertulisnya siswa yang berkemampuan matematika tinggi mampu mengaitkan konsep yang relevan dengan menamai konsep menggunakan huruf-huruf dan simbol tertentu untuk melaksanakan prosedur matematik seperti simbol " $\angle$ " yang melambangkan besar sudut, dan simbol " $\frown "$ yang melambangkan panjang busur. Pada saat wawancara berlangsung juga ditemukan bahwa siswa yang berkemampuan matematika tinggi dalam hal memahami masalah membaca sampai dua kali. Hal ini menunjukkan bahwa dalam hal merespon masalah siswa berkemampuan matematika tinggi cepat memahami masalah.

\section{Keterbatasan Penelitian}

Melalui penelitian ini telah diperoleh data empirik, namun masih terdapat beberapa keterbatasan sebagai berikut.

1. Masalah lingkaran dalam penelitian ini merupakan masalah rutin terapan sehingga siswa memiliki prosedur penyelesaian masalah secara rutin dan memiliki satu cara penyelesaian masalah. Hal ini merupakan suatu keterbatasan bagi peneliti karena soal rutin cenderung kurang mengekspolarasi pemahaman siswa lebih tajam.

2. Teori yang digunakan untuk mengungkapkan pemahaman relasional dalam pemecahan masalah pada tesis ini dirasakan belum lengkap, karena belum ditemukan literaturliteratur yang mengkaji suatu hasil penelitian tentang pemahaman relasional, apalagi 
literatur yang mengkaji hubungan pemahaman relasional dengan kemampuan matematika dalam memecahkan masalah matematika. Literatur-literatur itu dirasakan sangat penting bagi peneliti karena dengan adanya literatur-literatur tersebut akan lebih memperkuat data empirik yang diperoleh dalam penelitian ini. Keterbatasan dalam penelitian ini, menyebabkan analisis terhadap pemahaman relasional siswa hanya terbatas data empirik dan didukung oleh teori yang ada.

Dengan adanya keterbatasan dalam penelitian ini sebagaimana yang telah dikemukakan di atas, maka diharapkan adanya penelitian lanjutan untuk memperkaya penelitian ini. Penelitian lanjutan yang dilakukan sebagai berikut.

1. Penelitian untuk memperoleh pemahaman relasional dalam memecahkan masalah matematika dengan menggunakan jenis masalah non rutin terapan atau open ended agar mampu mendeteksi pemahaman relasional siswa lebih tajam lagi.

2. Penelitian untuk memperoleh pemahaman relasional dalam memecahkan masalah matematika yang berbeda dengan materi yang diteliti, misalnya materi geometri lainnya seperti bangun ruang dan materi operasi hitung aljabar.

3. Penelitian yang melibatkan siswa dengan karakteristik yang berbeda dengan karakter siswa yang diteliti. Misalnya karakeristik berdasarkan gender, untuk melihat bagaimana pemahaman relasional perempuan dan laki-laki dalam memecahkan masalah matematika dan juga karakeristik berdasarkan gaya belajar, untuk melihat bagaimana pemahaman relasional siswa berdasarkan gaya belajar dalam memecahkan masalah matematika.

\section{PENUTUP}

\section{Kesimpulan}

Berdasarkan hasil penelitian yang telah dikemukakan peneliti dapat menarik beberapa simpulan tentang pemahaman relasional siswa SMP berkemampuan matematika tinggi dalam Pemecahan Masalah Lingkaran sebagai berikut.

a. Tahap Memahami Masalah

Siswa yang berkemampuan matematika tinggi mampu mengaitkan apa yang ditanyakan dan apa yang diketahui dengan cara mengkonstruksi gambar dengan benar.

b. Tahap Menyusun Rencana

Dalam hal kemampuan mengaitkan konsep baru dengan konsep yang dipahami untuk membangun prosedur matematik, siswa yang berkemampuan matematika tinggi mampu mengenali kaitan konsep yang dipahami dengan baik, yaitu : mengaitkan 
konsep lingkaran (jari-jari lingkaran) dengan besar sudut persegi panjang $=90^{\circ}$, besar sudut segitiga sama sisi $=60^{\circ}$, besar sudut garis singgung/garis tegak lurus/sudut sikusiku $=90^{\circ}$ agar dapat menentukan besar sudut pusat di depan busur yang selanjutnya digunakan menentukan panjang busur, kemudian mengaitkan konsep lingkaran (jarijari lingkaran) dengan panjang sisi persegi panjang atau panjang sisi segitiga sama sisi untuk menentukan panjang garis singgung persekutuan luar lingkaran. Kemudian menjumlahkan semua panjang busur dan semua panjang garis singgung yang diperoleh tersebut. Selain itu, siswa yang berkemampuan matematika tinggi mampu mengingat rumus-rumus/algoritma yang rencananya digunakan untuk menyelesaikan masalah dengan tepat, yaitu : rumus panjang busur, rumus keliling lingkaran, dalil jumlah sudut satu putaran $=360^{\circ}$, dan rumus panjang garis singgung persekutuan luar lingkaran)..

Dalam hal kemampuan menjelaskan penggunaan prosedur matematik, siswa yang berkemampuan matematika tinggi mampu menjelaskan prosedur atau langkah-langkah penyelesaian masalah dengan benar. siswa yang berkemampuan matematika tinggi juga mampu menjelaskan secara tepat sifat dari konsep yang dikenali dengan benar (sifat persegi panjang, sifat segitiga sama sisi, sifat garis singgung, dan sifat garis yang tegak lurus). Selain itu, siswa yang berkemampuan matematika tinggi juga mampu menjelaskan secara logis alasan penggunaan rumus keliling lingkaran dalam penentuan rumus panjang busur.

c. Tahap Melaksanakan Rencana

Dalam hal kemampuan mengaitkan konsep baru dengan konsep yang dipahami untuk membangun prosedur, siswa yang berkemampuan matematika tinggi mampu menyelesaikan masalah sesuai rencana; siswa yang berkemampuan matematika tinggi mampu menggunakan rumus yang direncanakan dengan tepat yaitu menggunakan rumus panjang busur, rumus keliling lingkaran, dan dalil jumlah sudut satu putaran penuh $=360^{\circ}$. Siswa yang berkemampuan matematika tinggi mampu menemukan jawaban masalah dengan benar. Untuk menemukan jawabannya tersebut siswa yang berkemampuan matematika tinggi mampu mengaitkan konsep-konsep yang diperoleh (panjang busur dan panjang garis singgung) dengan cara menjumlahkannya sesuai yang direncanakan pada tahap menyusun rencana.

Selanjutnya dalam hal kemampuan menjelaskan penggunaan prosedur matematik, siswa berkemampuan matematika tinggi mampu menjelaskan secara logis alasan penentuan besar sudut pusat yang digunakan dalam penentuan panjang busur, siswa 
yang berkemampuan matematika tinggi juga mampu menjelaskan secara logis alasan menentukan panjang garis singgung persekutuan luar berdasarkan panjang sisi persegi panjang atau panjang sisi segitiga sama sisi.

d. Tahap Memeriksa Kembali

Dalam hal kemampuan mengaitkan konsep baru dengan konsep yang dipahami untuk membangun prosedur, siswa yang berkemampuan matematika tinggi mampu mengaitkan penyelesaiannya dengan apa yang diminta soal dengan melakukan pemeriksaan hasil hitungan (penggunaan rumus/algoritma atau operasi hitung) sebanyak dua kali yaitu dilembar jawaban dan lembar coret-coretan.

Selanjutnya dalam hal kemampuan menjelaskan penggunaan prosedur matematik, berkemampuan matematika tinggi mampu menjelaskan secara logis hasil jawaban yang diperoleh berupa penjelasan terhadap penggunaan rumus beserta operasi hitungnya dengan tepat dalam memeriksa kembali penyelesaian yang telah dilakukan.

\section{Saran}

Berdasarkan hasil pembahasan dan simpulan yang diperoleh maka ada beberapa saran yang dapat dikemukakan untuk guru matematika dan peneliti selanjutnya, sebagai berikut:

1. Hasil penelitian menunjukkan terdapat perbedaan pemahaman relasional siswa yang berkemampuan matematika tinggi, sedang, dan rendah dalam pemecahan masalah lingkaran. Untuk itu, direkomendasikan kepada guru matematika untuk memperhatikan temuan tersebut sebagai bahan masukan untuk menyusun pembelajaran yang mengakomodasi perbedaan kemampuan matematika untuk mengoptimalkan pemahaman relasional yang dimilki siswa.

2. Mengingat pemahaman relasional memiliki kaitan yang erat dengan koneksi matematika maka perlu direkomendasikan untuk melakukan penelitian lebih lanjut tentang hubungan antara koneksi matematika dengan pemahaman relasional.

3. Perlu dilakukan penelitian lanjutan dengan memperhatikan keterbatasan yang ada dalam penelitian ini, dengan demikian disarankan untuk melakukan penelitian dengan karakteristik siswa yang berbeda dan materi yang berbeda, dengan karakteristik siswa dan materi yang telah diteliti sehingga pada akhirnya hasil yang diperoleh akan lebih memperkaya hasil penelitian ini.

\section{DAFTAR PUSTAKA}

Anderson, O.w \& Krathwohl.D.R. (2001). A Taxonomy for Learning Teaching, and Assessing (a Revision of Blooms Taxonomy of Educational Objectives) Addision Wesley, Longman New York. 
Arifin, Zaenal. (2009). Membangun Kompetensi Pedagogies Guru Matematika (Landasan Filosofis, Historis, dan Psikologi). Surabaya : Lentera Cendekia.

Bamby., Harries, T., Higgins, S., Suggate, J. (2007) "How can Asses Mathematical Understanding" Proceedings of the 3ist Conference of the International Group for the Psychology of Mathematics Education. PP. 41-48.Seoul : PME).

Hamdani. (2013). Proses Koneksi Matematika Siswa SMK PGRI 7 Malang dalam Menyelesaikan Masalah Berdasarkan Pemahaman Skemp. (Tesis Magister Pendidikan tidak dipublikasikan).Universitas Negeri Malang.

Miles \& Huberman. (2009). Analisis Data Kualitatif. Jakarta : UI-Press

National Council of Teachers of Mathematics. (2000). Curriculum and Evaluation Standards for School Mathematics, Reston, Virginia: NCTM.

Piaget."Tahap Operasional Formal".Diakses dariwww.asikbelajar.com/2013/01/piaget-tahapoperasional-formal.html

Prasetyo.(2013). Analisis Perilaku Penyelesaian Masalah Soal Cerita Keliling dan Luas Lingkaran Melalui Tahapan Analisis Kesalahan Newman Pada Siswa Kelas IX H SMPN 2 Malang. Tesis Magister Pendidikan tidak dipublikasikan). Universitas Negeri Malang.

Polya, G. (1981). Mathematical Discovery on Understanding, Learning, and Teaching Problem Solving. United States of America.

Shadiq, Fadjar. (2008). Psikologi Pembelajaran Matematika di SMA: Paket Fasilitas Pemberdayaan KKGMMGP Matematika. Yogyakarta : P2PTK.

Siswono, Tatag Yuli Eko. (2008). Mengajar dan Meneliti. Surabaya : Unesa University Press.

Skemp, Richard R. (1976). Relational Understanding and Instrumental Understanding. First Published in Mathematics Teaching: University of Wawick.

Skemp, R. R. (1987). The Psychology of Learning Mathematics. New York: Penguin Books Ltd.

Utomo. (2010). "Pengetahuan Konseptual dan Pengetahuan Prosedural Dalam Pembelajaran Matematika". Makalah disampaikan pada seminar nasional matematika Universitas Muhammadiyah Malang pada tanggal 10 januari 2010). Universitas Muhamadiyah Malang. http:dwipiumm@yahoo.com. diakses tanggal 5 April 2014 pkl 08.45 .

Wahyudin. (2003). “Peranan Problem Solving”. Makalah disajikan pada seminar Nasional FMIPA UPI Bandung Tanggal 14 April 2003. UPI Bandung.

Wardhani. (2008). Paket Pemberdayaan Matematika KKG Matematika: Analisis SI dan SKL Mata Pelajaran SMP/MTs untuk Optimalisasi Tujuan Mata Pelajaran Matematika. Yogyakarta : P2PTK Matematika Kemendiknas \& Balitbang.

Widhiharto. (2008). Aplikasi Teori Belajar dan Diagnosa Kesulitan Belajar Matematika SMP dan Alternatif Proses Remidinya. Yogyakarta : P2PTK Matematika. 